\title{
A Woman's Place: Women of Colour Navigating Doctoral Education in South Africa
}

\author{
Cyndy R. Snyder \\ University of Washington - Tacoma
}

U. S. A.

ABSTRACT: The purpose of this study was to investigate the experiences of women of colour in South African doctoral education programmes. Through qualitative interviews with African, Indian, and Coloured female doctoral students, this study illuminates the challenges women of colour doctoral students face in progressing through doctoral education in South Africa, and the supports they utilize to help them persist and complete doctoral degrees. Findings are organized around four themes: (1) challenging race and gender stereotypes and expectations; (2) balancing multiple roles; (3) managing financial concerns and access to resources; and (4) finding support and encouragement. This study holds implications for how institutions of higher education can help support female students of colour in navigating their programmes.

\author{
Literature Review \\ Methods \\ Results \\ Discussion \\ Implications and Conclusion \\ Notes \\ Acknowledgment \\ References
}

While the primary goals of recent efforts towards higher education transformation in South Africa were to remedy the legacy of apartheid by broadening access to institutions of higher education to historically disadvantaged groups, ${ }^{1}$ particularly students of colour and women, the gap between enrollment, persistence, and attainment of the doctoral degree still exists. This gap is particularly apparent for women of colour. ${ }^{2}$ On the positive side, the number of women of colour obtaining doctoral degrees has grown over the years from about 1\% to 11\% between 1996 and 2006 (Herman, 2010). Still, the majority of doctoral programme graduates in South Africa are White and male (ASSAF, 2010). Understanding the lived experiences of women doctoral students 
of colour helps shed light on factors that might contribute to or hinder persistence and completion in doctoral programmes. A good deal of research coming out of the United States has focused on the experiences of students of colour in graduate education (Felder, 2010; Gildersleeve, Croom, \& Vasquez, 2011; Griffin, Muniz \& Espinoza, 2012; Nettles, 1990; Taylor \& Antony, 2000; Willie, Grady \& Hope, 1991), but a smaller body of work has focused on understanding the experiences of women of colour specifically. There is an even smaller body of literature that has sought to understand the experiences of women of colour in the South African higher education context.

Previous research on the experiences of students of colour in doctoral programmes has found that students of colour endure a number of experiences that push them out of doctoral education, including poor or insufficient advising and mentoring relationships with faculty (Bertrand Jones, Wilder, \& OsborneLampkin, 2013; Gay, 2004); academic and personal invalidation from peers, professors, and staff (Lewis, Ginsberg, Davies, \& Smith, 2004); lack of departmental and institutional support (Lewis et al., 2004; Nettles, 1990; Portnoi, 2009); and a campus racial climate that is alienating and isolating to students of colour (Gay, 2004; Gildersleeve et al., 2011; Lewis et al., 2004; Portnoi, 2009; Smith, 2004; Solórzano \& Villalpando, 1998; Soudien, 2010). Research suggests that such experiences may be exacerbated for women of colour as they are further marginalised, excluded, and isolated due to the patriarchal nature of academia and the intersections of race and gender discrimination (Ellis, 2001; Potgieter, 2008; Turner \& Thompson, 1993), forcing them to navigate an environment that frames them as unintelligent, hostile, or overassertive (Allison, 2008; Carter-Black, 2008; Cole \& Guy-Sheftall, 2003; Collins, 2000; Evans, 2007; Johnson-Bailey \& Cervero, 2008).

While research on the status of doctoral programmes in South Africa provides useful information on overall participation rates and trends, studies lack information disaggregated by race and gender as well as information regarding student experience and explanations for attrition. Using critical race feminism and theories of campus climate as lenses through which to view the experiences of women of colour in doctoral education in the South African context, the goal of this study was to illuminate the unique experience of women of colour in an effort to better support their pursuit of higher education.

\section{Review of Literature}

The following review of literature attempts to situate this study in the context of what is already known about women of colour in higher education. I first discuss the literature on women of colour in higher education and describe critical race feminism as a lens through which to view the experience of women on colour. Second, I review research on campus racial climate and its influence on the experiences of students of colour. Finally, I discuss literature on the South 
African context, paying particular attention to studies that have focused of women of colour in the academic context.

\section{Women of Colour in Higher Education}

Women of colour in higher education face a multitude of barriers en route to their degrees. Studies have found that Black women at historically White institutions felt isolated, alienated, and, at times, invisible (Evans, 2007; Grant, 2012; Mahtani, 2004; Shavers \& Moore, 2014). A recent qualitative study by Shavers and Moore (2014) explored the various coping strategies Black women used to navigate their doctoral programmes. This study found that women often employed the "academic mask," in which one takes extra measures such as varying their grammar, appearance, and interactions to combat the negative stereotypes about Black women, efforts that White women presumably do not have to undertake to the same extent. However, some of the interviewees also discussed the toll that such processes took on their well-being, forcing them to compartmentalize the academic self from the personal or authentic self. Jones and Shorter-Gordon (2003) refer to this phenomenon as "shifting" and point out that such actions can lead to psychological problems such as depression and anxiety.

Mentoring is an often-proposed remedy to combat the negative mental and occupational impacts of subpar educational experiences. However, effective mentoring for women of colour in doctoral programmes may need to look different from traditional notions of mentoring often grounded in White, malecentric frameworks (Bertrand Jones et al., 2013; Harris, 1999). For example, a study of Black women in educational leadership programmes found that interviewees expressed the importance of having a mentor of the same race and gender, who goes beyond the traditional notions of mentoring by providing a culturally relevant and nurturing peer-mentor role (Grant, 2012; Grant \& Simmons, 2008).

Critical race feminism (CRF) offers a lens through which to understand the experiences of women of colour in higher education. Rooted in a combination of critical race theory and feminist theory, CRF centers the intersections and complexities of both race and gender for women of colour (Crenshaw, 1991; Collins, 2000; Pratt-Clarke, 2010; Wing 2003). Evans-Winters \& Esposito (2010) articulate the value of using a CRF framework in the educational context and describe CRF as providing a transdisciplnary lens that (a) centers the intersectionalities and complexities of race, class, and gender for women of colour, (b) recognizes that their experiences and perspective are different from those of men of colour as well as White women, (c) recognizes multiple forms of discrimination and oppression based on race, class, and gender, (d) is antiessentialist and recognizes the unique experiences of women as individuals, and (e) provides a call to action in which theory and practice are combined to combat multiple facets of oppression. This transdisciplinary approach may help 
conceptualize research on the experiences of women of colour in higher education as well as design programmes and services to support their development and success.

As Pratt-Clark (2012) noted, "Storytelling and personal narratives allow women of colour to discuss their experiences within a racist and patriarchal society" (p. 84). Thus, critical race feminism offers a valuable lens through which to center the unique experiences of women of colour in South African doctoral education, particularly in light of the historically White, patriarchal systems of domination that have contributed to the educational inequalities for women.

\section{Campus Racial Climate}

Campus racial climate can be described as the overarching feel and structure of the campus norms, policies, attitudes, and services afforded to communities of colour on campus (Hurtado, Milem, Clayton-Pedersen, \& Allen,1999; Solórzano, Ceja \& Yosso, 2000). Campus climate shapes the extent to which faculty, staff, and students of colour feel welcomed, respected, and valued by the university. Scholars who study campus climate discuss the importance of the interconnected aspects of the campus environment including the institution's historical legacy of exclusion of various groups, the numerical representation of people of colour on campus (structural diversity), the attitudes and interactions between and among different ethnic groups on campus (behavioral and psychological aspects), and campus policies (Hurtado et al., 1999; Milem, Chang, \& Antonio, 2005).

Johnson, Wasserman, Yildirim, and Yonai (2013) used path analysis to explain the relationship between campus climate and retention for students of colour and White students. They found that for students of colour, observing and encountering racism increased their stress levels and decreased their positive feeling about the campus climate, ultimately leading to attrition. Numerous other studies have found that an unwelcoming campus racial climate is associated with feelings of isolation, students' feeling less committed to the institution, and higher rates of attrition for students of colour (Griffin et al., 2012; Hurtado \& Carter, 1997; Solórzano et al., 2000; Wei, Ku \& Liao, 2011). An interesting study by Griffin et al. (2012) explored the role of campus racial climate in Graduate Diversity Officers' ability to recruit and retain a diverse group of doctoral students. Situating their findings in the theoretical framework of campus racial climate, they concluded that campus racial climate impacts not only retention, but also recruitment of students of colour; thus, efforts to improve the campus racial climate at all levels can also help attract a diverse group of students to doctoral programmes.

Understanding campus racial climate in South Africa for women of colour in doctoral programmes is integral to understanding their experiences. As campus climate theories and research point out, being both a woman and a 
person of colour in a space that has historically been dominated by males and designed to maintain White privilege can take a toll on women's psyches and, ultimately, academic trajectories.

\section{Higher Education for Women of Colour in South Africa}

South Africa has made gains over the years in terms of race and gender equity, but women, and women of colour specifically, still remain underrepresented and underserved in many institutions of higher education. Additionally, the women who do make it into academia are often employed at the lower administrative or faculty ranks (Mabokela, 2004; Shackleton, Riordan \& Simonis, 2006). To keep a pulse on gender and race equity in higher education systems, institutions report data on race and gender to the Ministries of Education. However, these statistics are not consistently parsed out to show the number of women who are Black or vice-versa, thus overlooking the intersectionality of race and gender disparities and their impact on the lives of these women. Furthermore, numbers alone cannot tell the full story of how welcoming or hostile the campus racial climate is or how women of colour experience their programmes and institutions.

There have been a few studies focusing on women of colour in South African higher education systems, providing some insight on the perspectives of both students as well as professionals. For example, Mabokela (2004) interviewed women of colour at historically Black institutions about their experiences. Interviewees in her study pointed out that they had difficulty in finding mentoring and support for professional development opportunities; encountered a patriarchal, male dominated culture that framed women as inferior or incompetent; experienced interracial and interracial bias from Whites and other people of colour (e.g., Indians racially biased against Africans); and encountered a lack of clarity and consistency in the promotion and tenure process. Similarly, Potgieter and Moleko (2004) studied the experience of women of colour at historically White institutions and had similar findings to Mabokela (2004) in that interviewees discussed experiences of race and gender bias they encountered at the individual and institutional level.

These studies reiterate that, although laws and policies exist to mitigate race- and gender-based discrimination, they do not eradicate the racism and sexism ingrained within the higher education system, realities that take a toll on the lived experiences and psyche of women of colour. While many studies in the South African context have focused on the experiences of women of colour already in administrative or faculty positions in academia, this study seeks to further the conversation about the complex experiences of women of colour by focusing specifically on women who are currently in their doctoral programmes, in an effort to identify early interventions that can impact the pipeline and continue to identify means to address the deeply ingrained racism and patriarchy. 


\section{Methods}

This exploratory study employed a narrative methodology to shed light on the experiences of women of colour in South African doctoral programmes and provide insight regarding how to improve the opportunities for women of colour to successfully progress through doctoral education. Narrative methodology centers on the individual's unique story and helps illuminate their lived experiences. Narratives are beneficial in that they not only provide in-depth understanding into the perspectives and experiences of an individual but can also enable people to reflect upon and make sense of their own experiences (Ladson-Billings, 1999). This study focused specifically on women because research supports that the climate for women of colour in higher education is different from the climate for men due to intersections of race and gender discrimination (Bertrand Jones et al., 2013; Evans-Winters \& Esposito, 2010). These differences have the potential to differentially impact women and their ability to navigate and complete their degrees.

Specifically, this study sought to answer the following research questions:

1. What challenges do women of colour doctoral students face in progressing towards a doctoral degree?

2. What supports do women of colour doctoral students utilize to help them persist and complete doctoral degrees?

Snowball and purposive sampling (Patton, 1990; Weiss, 1994) were used to select participants. Administrators and academic staff in the Faculties of Education at institutions in the Western Cape were asked to post the study announcement and refer students who met the sampling criteria. To be included in the study, participants must have met the following sample criteria: (a) be currently enrolled in a doctoral programme in the field of education, (b) reside in the Western Cape, and (c) identify as African, Indian, or Coloured.

Five women doctoral students volunteered to share their stories of navigating their doctoral programmes. Interviews took place in person and lasted between 90-120 minutes. Follow-up interviews were conducted with select participants to elicit additional information where needed. Two of the participants' institutions were historically Coloured institutions and one was a historically White institution. As a large proportion of women of colour pursuing doctoral education do so in the field of education (ASSAF, 2010), this study focuses specifically on women of colour in the field of education. Interviewees were at various stages in their programmes; some were in their first year while others were working on their final theses. Three of the interviewees worked full time at the institution in which they were pursuing their doctoral degrees, and two worked full time outside of the university environment in schools or government organisations. All of the women had children, and all but one were married. All 
names and identifying information have been changed to protect the confidentiality of the participants. Research processes were approved by the institutional ethics committee to ensure that ethical guidelines were met.

Interviewees were asked questions about challenges and sources of support encountered as women of colour navigating their doctoral programmes. Participants were free to decline to answer any questions they chose or stop the interview at any time. Interviews were transcribed and subsequently analysed using a grounded theory method in which themes arising from the data were identified and used to code transcripts (Strauss \& Corbin, 1990). The constant comparison method was employed to identify response patterns and themes (Charmaz, 2006; Lincoln \& Guba, 1985) and codes were developed to identify and categorize responses.

\section{Results}

The following section presents the findings of the interviews. I first discuss the major themes that arose regarding challenges faced in the process of their doctoral studies: challenging race and gender stereotypes and expectations; balancing multiple roles, and financial concerns and access to resources. I then discuss sources of support discussed by the interviewees, including instrumental people as well as practices that help to sustain them.

\section{Challenging Race and Gender Stereotypes and Expectations}

One salient theme that arose from the conversations with interviewees was that they had to learn to navigate, and often challenge, expectations regarding what was acceptable and achievable for women, particularly women of colour. Specifically, interviewees spoke of having to prove their worth or work twice as hard as their White counterparts, experiencing gender and racial microaggressions, and negotiating sexism and notions of traditional gender norms.

Terry, an administrator at a local university, illustrates the concept of having to prove oneself as tied to cultural capital. She notes:

They [White students] just seem to have the tools to do it better and we can't do it with the same ease. Because in a sense this is simulated for us....You enter that space and it's not a natural progression from the other aspects of your life. You almost step into a space that may not totally be real and now you need to play the role. Whereas other people come in quite comfortably, straight out of their cars in to this space, out of their homes and they don't have to negotiate anything else in between....Some people argue it is perhaps the cultural capital that White scholars have. 
Cheryl's comment also illustrates this point: "I think in that sense,... being nonWhite, you have to always work a bit harder or insist. Nothing is just going to happen."

Racial and gender microaggressions were also discussed as being a challenge unique to being a woman of colour. The term "microaggressions," initially coined by Chester Pierce $(1970,1974)$, was later defined by Sue et al. (2007) as "brief and commonplace daily verbal, behavioral, and environmental indignities, whether intentional or unintentional, that communicate hostile, derogatory, or negative racial slights and insults to the target person or group" ( $p$. 273). Interviewees often noted trying to disentangle whether something was racially motivated, gender motivated, or both. For example, Terry notes:

I think as a Black woman ... it's often a hunch, not something that you can prove. It could be a perception, it could be your own baggage but for example when we go to [institution] our perception is that we are not as good. ... we feel that perhaps at certain times we are not taken seriously. We can't prove that and it's difficult to analyse, it's just a hunch, you know baggage.... So I wonder if that's a burden that we carry, something that we have to manage being Black.

A commonly mentioned experience discussed by the interviewees involved negotiating explicit or implied assumptions about a woman's role, often rooted in patriarchal norms. Ellen and Lindy's comments illustrate such experiences. When asked about her experience as a woman of colour in a doctoral programme, Ellen noted:

Being a so-called "Coloured woman" in South Africa and being the age that I am, we grew up in that apartheid era. We grew up with the notions of you know women are kept down there. You have a job to do, a very stereotyped way of growing up....So you go and you're a teacher and you earn this little salary and that is just the way it should be until years later when you start to question. So what I'm saying is; a lot of my reluctance to go further was as a result of me not really having been educated as such. I'm a Coloured woman, how on earth can I have a degree? It's way out of my reach.

However, Ellen went on to discuss how challenging such notions also fueled her drive to persist. She went on to add:

I know yeah I'm a woman and I know I'm a Black woman and maybe it's that earnestness that I have to succeed at this because people are going to be looking and say "aah you know she's a Black woman, what did you expect."

In a similar notion, Lindy discussed her experiences and challenges in the programme as being directly tied to the expectations placed on her as a woman:

...it is a female thing. I don't think it would be the same if I was a man because just automatically, it's just expected that you need to do this, that, and the other I would imagine. The biggest challenge for me is time. You 
know to do everything at work and home and the studies. It just so happens that it does become a gender thing because I'm the mother, the person that needs to keep things happening at home.

Such challenges and limited views about gender roles often resulted in having to negotiate multiple roles that they felt they would not have had to juggle had they been men. The next section speaks extensively to this theme.

\section{Negotiating Multiple Roles}

The theme of having to negotiate multiple roles and expectations was highly salient among all interviewees. Interviewees spoke of having to find balance while juggling multiple roles of mother, spouse, professional and student. Some also discussed the fear of not being a good parent, which was a high priority for all of the women, and the guilt that this balancing act created.

Each of the interviewees had children and family responsibilities that they were highly committed to. Terry's comment illustrates the stress associated with trying to fulfill multiple roles:

As a woman, I cannot shake the other kind of institutionalised roles that I have come to play with ease. I can't just dismiss them in a sense.... I have to look at how I'm going to deal with that, being a good mother whatever that means, being a good partner, being active in the community. I don't know how to merge and to hold the energy for that without putting my entire life on hold for this $\mathrm{PhD}$ experience. Yeah to work against the selfishness, the self-indulgence if you like.... There are challenges that I'm gonna face I think, and I think it's just the early days and I don't know the extent to which I'm going to be pulled in different directions.

The women also discussed how they went about managing these multiple responsibilities and expectations. The experiences of Ellen and Cheryl provide two examples of attempting to balance the multiple roles and responsibilities. Ellen's quote eloquently articulates how she strives to balance multiple roles and responsibilities:

I'm a wife so I have to spend time with my husband. I'm a DeputyPrincipal of a school so the responsibility is great.... have a full time class in addition to being the Deputy-Principal so I have to see to all my responsibilities as the Deputy-Principal, all the administration and I have to see to my class and the subjects that I teach and I have to see to the staff and the parents and, it's crazy! Then I've got my grandchildren and I've got my studies and then l've got a family too, an extended family. I've got a mom... and for me my mom is very important so after school I first pop around there by her; see that she is ok, see to her needs. So you know it's chopping up those hours finely.... had to sit them [family] down and say look I need to finish this and in order for me to finish this I need the time, I 
need the space, I need the quiet. I need nobody to come to me and pat me on my shoulder and ask me for something.

While Ellen consciously made efforts to take the space she needed to balance her family and school responsibilities, Cheryl had a more difficult time carving out a space. She noted:

You notice the woman's role has changed. They're working and they are doing all kinds of things but they still have to do their role that they were sent out to do. So it makes it quite difficult. I mean you have to work and then you have to pick up kids, drop kids, you know the aftercare and then you still have to do grocery shopping and then you have to go home and you have to do the cooking. So by the end of the day about 8 , half past 8 you know you are just too tired to do anything after that.

Cheryl went on to add:

I think if I ask for support then they would but I try to manage everything on my own so at the moment l've insisted on a space in the house which I could call my own because the two boys have their own little desk in their room and I have been sharing their space and my husband's got the study for himself so I said that's unfair. So during the holidays I managed to clear out half the study and bought myself a desk and a table so now that is my space.... I think maybe at some point I need to speak to them at home. I'm sure they would understand ....I mean my husband wouldn't mind taking over some tasks and doing some work. That's the only way I mean, if I really want to get started then that's the only way.

In addition to family roles, each of the women also worked full time in professional roles, often at the institution where they were completing their doctorates or other education related organisations. Thus, finding time to balance work, life, and school also posed challenges. In speaking about an upcoming project at work, Ellen discussed how she prioritizes her work and school responsibilities.

I have to get my marking done and I have to sit with my research. I said to myself, "listen for the next two weeks put your research aside and get this done. This is your job, this is your bread and butter, this is priority. Get this done. As soon as this is done then we can go full time at it [research]." I have to otherwise I will go crazy.

Each of the women placed their roles as mothers, and sometimes grandmothers, as a top priority. In light of this, many of the women spoke of the fear and guilt of not living up to their roles as mothers while trying to balance school and professional life. Cheryl, who earlier discussed her difficulty in finding space to focus on her studies, illustrates this point:

I just feel guilty.... I grew up with my mum being at home and my mum's always there to provide for us... and then we're working and so it's very strange for me to be working and then not be there to drop off kids and pick up kids and have a hot meal ready for them when they come home. 
So that was something difficult...I find doing my PhD, this is for me, this is for myself so I don't think it's fair me asking them to give up certain things just so that I could carry on with my studies.

As the above stories illustrate, balancing work, family, and school proved challenging for all of the interviewees. Women struggled with challenging traditional patriarchal assumptions about a women's role and their own internalized expectations of the role of women as wife and mother in contrast to professional and student.

\section{Financial Considerations and Access to Resources}

Financial and financially related concerns regarding access to resources were also mentioned by interviewees as a reason for their choice in a particular programme as well as variables that posed, or could potentially pose, challenges during the course of their programme.

Phinda, a high level university administrator, discussed why she chose the programme she did and how financial consideration impacted this choice:

Looking at the economic situation in the country and looking at the role of women and how many women are managing their families independently, financial issues can also hinder the progress, or their ambition for studying....When I worked at other institutions that didn't have PhDs that were interesting to me, it would imply that I have to enroll in another institution and then there would be hidden costs like travelling, leaving my kids alone.... Those were the issues and I presume people that are not working at Universities have. How do they afford it? Because a PhD on its own is about twenty something thousand, let alone the travelling cost, let alone the books, and access to resources. Even laptops, because you can't study without technological gadgets to communicate with your supervisor.

Lindy and Cheryl also noted the benefits of working at the institution in terms of access to resources and support. Lindy, who did not work at the university but worked full time in a professional capacity in the field of education, commented about how those who work on campus have greater access to resources, including their advisors. She stated:

I think it helps if you're working at the University. You are there, your supervisor is there, they're aware of the fact that you are studying and I'm sure they are supportive to those people. In terms of their workload and everything else so they certainly have an advantage in my opinion you know.

Supporting Lindy's assertions, Cheryl, who did work at the institution where she was pursuing her doctorate noted: 
Yeah if you look at the PhD programme, it's more expensive at [other institution] than here and I think the reason why I choose here was two reasons. Firstly, it's just convenient. I'm in the Faculty, if I need to see my supervisor or whatever, it would just be easier and then also you don't have to pay fees. You just pay admin fee being a staff member.

While many of the women had jobs on campus that allowed them to pursue work and school life simultaneously, some who did not work on campus contemplated the idea of taking time off work to focus on studies, potentially putting even larger financial burdens on them and their families. Ellen discussed the financial toll of pursuing doctoral education as tied to the fear of not being financially stable.

So my husband said to me; why don't you stay at home for the year. Finish your study and then go and lecture after you have finished your study.... am so afraid of not being financially stable. And I think that's a Black thing. We are so afraid of not having because of the struggles we had, because of what we had to do. How far we had to go. How we had to work to get to where we are. And to have this comfort and now to just let it go.

Building on this experience, when asked what sources of support or assistance would be useful in helping her complete the programme, Lindy, who also did not work on campus, commented that financial support in the form of bursaries (scholarships) might allow her to take some time off work to focus more on her studies and better balance family and school responsibilities.

\section{Finding Support and Encouragement}

While there were numerous experiences that posed challenges in progressing through their doctoral programmes, the women also noted the sources of support and encouragement they relied upon along the way. Such sources included peers and colleagues, supervisors, friends, and family members.

Terry discussed the benefit of support and discussion groups in processing material and finding common ground with other students. She noted:

I think the one thing that we have established is a PhD support group and a discussion group. So we meet once every two weeks to thrash out, to discuss, to decode to deconstruct things at our level....I think we are forming a small community which is very important.

Likewise, Phinda and Lindy acknowledged the benefit of such groups, but also pointed out that coordinating and maintaining such groups could be difficult because of scheduling conflicts and practicalities. Phinda stated:

We work very well together but all of us are working females with families and we kind of give each other support that we can in terms of phoning each other, motivating one another but the issue is what we planned to do 
is very, very impractical. We thought we would have meetings, forums where we sit together to see how far we are; where your challenges were and assist each other. But it becomes very impractical because we're all working.

Interviewees also found support, both academically and personally, from peers and colleagues in more informal ways. For example, Cheryl discussed both organising meeting times with peers and how they supported each other outside of those specific meetings.

We just get together and meet and chat about it and you know look at where's everybody at and what they're doing and the challenges just so that you find you are not alone. And most of the time as females chatting about it, we end up talking about home issues and you know and how they accommodate, and the challenges of trying to balance home life with work....But also like when the one lady's proposal was due then we had a mock session where we got together and she presented to us and then we helped her out, so that way we provide support. But I think the biggest comfort is just knowing that you are not alone in whatever issues you are having when you speak to these other ladies about it.

Colleagues outside of campus also provided a source of support and encouragement. Ellen commented that her colleagues and community at the school she works were a great source of encouragement.

Their [colleagues'] expectations of me are so so high. They are so supportive and they push me all the time. They want to know how far I am because it's again this Black woman at our little Black/Coloured school doing that.... I can see how excited they are, I can see how proud they are because it's one of us you know, it's one of us. We've been together all our lives. So I don't know if that's a Black woman thing or you know just a colleague. But I think there might be subtle undertones of somebody achieving in our culture, in our race, somebody doing that, somebody achieving that.

In addition to peers and colleagues, interviewees also noted finding support and encouragement amongst their supervisors. For example, Ellen noted a sense of renewal after meeting with her supervisors. She noted:

When I have spoken to them [supervisors] I feel renewed, man! I really feel like they have a lot of faith in me.... s sort of come to a point where I can say, "Maybe I will be able to do it because they've been going on about this for a long time." Maybe I have it in me, you know, to get it done. And then when you are away for too long, the doubts start creeping in again and then I'm so happy when I can meet with them again because I know when I leave here, I feel ready again to tackle something.

Likewise, Cheryl spoke about the specific ways she feels her supervisor supports her progress: 
He understands and so he has been great giving me the space, the time and that kind of thing and also if I need to attend a workshop or conference or anything like I'm going next week to a doctorateness workshop. So yeah in that way he is really good and if he finds any articles or whatever, he is also very supportive. So that is no problem. I think that's a really good plus to have a supervisor who understands.

Friends and family were also discussed as a source of support and encouragement among the women. Ellen discussed the ways she feels supported by her husband even though he is not in the same career field:

...we would be driving and he would say to me, 'how far are you? When are you getting done? I don't see you working.' That's enough for me. That's support because he has no clue what I'm doing. He has no clue what it entails. He just sees me reading and typing all the time. That means the world to me, that really means the world to me.

Ellen also discussed finding solace and support in taking time to be with friends. In speaking about how she finds support and space to manage her multiple roles as wife, mother, grandmother, daughter, student, and professional, she noted:

I make a point of taking a break three times a week for an hour and a half. So I pick up my buddy and we just go for coffee. We sit in the restaurant, we have a smoke, we have our coffee. In an hour's time we get up and off we are at home again. We just need that and I promised myself I was going to do that for me.

Support and encouragement from friends, family, and colleagues was integral to helping women balance work, family, and school as well as find the will to persist. While working with peers in the programme sometimes proved challenging to find time or stay connected, such activities also helped motivate and find their way through a sometimes unwelcoming and isolating environment.

\section{Discussion}

The intent of this study was to understand the challenges women of colour doctoral students in South Africa face en route to their degree, and what supports they utilize to help them persist and complete doctoral degrees. Interviewees discussed various challenges throughout their educational trajectories, including experiences with racism and sexism ranging from blatant to subtle, both at the individual and the institutional levels. Interviewees also discussed how the competing responsibilities of work, family, and school weighed heavily in women's challenges. These women's struggle to find their place as a professional, scholar, wife, mother, and daughter, roles which often pulled them in various directions, presented challenges to their progression through their programme, as well as pushed them to reflect on their own personally held notions of the role of women in the workplace and their families. In addition, 
financial factors were a significant concern in determining whether or not to pursue a degree as well as which degree to pursue.

Regarding support, the interviewees often noted they turned to friends, peers, and family as sources of support and encouragement. While finding time to work with peers proved difficult in some circumstances due to time constraints and other obligations, interviewees also noted that spending time formally and informally with peers in their programmes helped them find common ground, knowing that others were facing similar situations and had similar feelings, and encouraged them to persevere.

This study reiterates many findings from previous studies of women of colour in higher education in both the US and South Africa. Supporting the findings of Griffin and colleagues's (2012) study of graduate diversity officers, the interviewees in this study also discussed the ways in which diversity and racism within the campus environment, availability of mentors, and access to financial resources influenced their decision to pursue their degrees as well as their experiences once in the programme. Likewise, the findings regarding experiences with racism and struggles to transcend the patriarchal assumptions about a woman's place mirror the findings of Mabokela (2004) and Potgieter and Moleko (2004), both of which articulate the continuing racial and gender inequality in South African higher education. The value of support networks of other women of colour was also articulated as a coping strategy in Potgieter and Moleko's (2004) study, further emphasizing the need for mentoring and peer networks to facilitate persistence.

As in previous studies, the role of campus climate in shaping women's experiences was salient in this study. The interconnectedness of numerical representation along with cultural assumptions and institutional histories and norms was evident in interviewees' narratives, thus supporting the notion that it is the cumulative and combined effect of all aspects of campus climate that shape experiences, not just any one specific factor.

While this study reiterates many findings from the literature on Black women and women of colour in general from both the US and South African perspectives, it furthers the conversation by centering the voices of students who are currently in their programmes, presumably on their way to administrative or faculty positions in the field of education, providing insight into what can be done to smooth the pipeline into the profession. Furthermore, this and other studies speak to the fact that the inequitable and racially charged experiences of women of colour in academia, either as a student or faculty members, are not isolated incidents. They cross national boundaries.

As with all research, there are a few limitations worth noting. First, the small sample size limits the generalizability and representativeness of findings. Therefore, findings should be contextualized as pertaining to a small group of interviewees in the Western Cape. Second, this study explored only the experiences of women in education programmes. Future research should also explore the experiences of women in doctoral programmes in other fields such as 
science or professional programmes such as law. Additionally, this study was focused on the Western Cape, and women in Gauteng could have vastly different experiences given the different racial dynamics in varying metropolitan provinces of South Africa. Finally, it is important to note that historically Black institutions were not represented in this study, and women's experiences at such institutions may be different from those at the historically White and Coloured institutions included in this study. Nonetheless, several implications can be gleaned from this study.

\section{Implications and Conclusion}

Despite efforts towards transforming higher education to be more diverse, women of colour are still underrepresented in academia in South Africa. To understand and address such underrepresentation, scholars and practitioners should more fully focus on the pipeline - understanding what happens to the growing number of women who enter doctoral programmes from the time they enter until they leave, with or without a degree. While the trials associated with being a woman of colour in academia will not end with the completion of the degree, changing the dynamics at the doctoral programme level is one way to begin to address the issues women of colour face in academia. Given that the interviewees noted struggles with assumptions of capableness based on race and gender, balancing work and family, and ensuring financial support was available, there are various ways that colleges and universities can better support these women.

As scholars who study campus climate note, structural diversity is important to improving the environment and establishing a "critical mass" of students who can relate to each other and challenge long held notions of who is and should be in academia. However, institutions cannot focus on structural diversity alone - increasing numbers is not enough. Institutions should also seek to address racist and sexist assumptions held by other students, faculty, and staff in an effort to dismantle the systems of domination and oppression still present in institutions of higher education. Additionally, because scholars have noted that experiences with race- and gender-based microaggressions may cause psychological stress, exacerbating students' sense that they do not belong and diminishing their ability to persist in a hostile campus environment (Constantine \& Sue, 2007; McCabe, 2009; Solórzano et al., 2000), helping students develop meaningful and productive ways to navigate such an environment is imperative to helping them persist through their programme.

One way to assist students in navigating and addressing such environments is through strong mentoring relationships. There is a need for quality mentoring and advising in doctoral programmes. In particular scholars have noted that a Black feminist approach to advising which considers the interconnected roles of race, gender, and socioeconomic status (Bertrand Jones et al., 2013), may be beneficial to women scholars of colour, both students and 
faculty. It is also important to note that this approach is founded on the notion that there must be a critical mass of faculty and mentor figures who are women of colour to support these students. Supporting students into and through the pipeline can help build a stronger foundation of women of colour in academia to support the upcoming generations of students.

\section{Notes}

1. Historically disadvantaged groups include people of African, Coloured, or Indian descent, per Act No. 46 of 2013: Broad-Based Black Economic Empowerment. See: Broad-Based Black Economic Empowerment Amendment Act [No. 46 of 2013] (Gazette 37271 Government Notice 55)

2. In this study, the term "Women of Colour" includes Africans, Coloured, and Indian women. In South Africa, many individuals from historically disadvantaged groups use the term "Black" as an overarching description for being a member of a disadvantaged group and sometimes interchange racial categories in descriptions of self; this is evidenced in this study by the ways in which women identified themselves as "Black" at one point and as "Coloured" or "Indian" at another. Thus, the term "Women of Colour" was chosen as a more inclusive and dynamic categorization.

\section{Acknowledgment}

I would like to acknowledge Dr. Rajendra Chetty for his support in this project.

\section{References}

Academy of Science of South Africa (ASSAF). (2010). The Ph.D. Study: An Evidenced-based study on how to meet the demands for high-level skills in an emerging economy. Pretoria: ASSAF.

Allison, D. (2008). Free to be me? Black professors. White institutions. Journal of Black Studies, 38, 641-662.

Bertrand Jones, T., Wilder, W., \& Osborne-Lampkin, L. (2013). Employing a Black Feminist Approach to doctoral advising: Preparing Black women for the professoriate. The Journal of Negro Education. 82(3), 326-338.

Carter-Black, J. (2008). A Black woman's journey into a predominately White academic world. Affilia, 23, 112-122.

Charmaz, K. (2006). Constructing grounded theory: A practical guide through qualitative analysis. Thousand Oaks, CA: Sage. 
Cole, J., \& Guy-Sheftall, B. (2003). Gender talk: The struggle for women's equality in African-American communities. New York: One World Ballantine.

Collins, P. H. (2000). Black feminist thought: Knowledge, consciousness, and the politics of empowerment. New York, NY: Routledge.

Constantine, M. G., \& Sue, D. W. (2007). Racial microaggressions as instigators of difficult dialogues on race: Implications for student affairs educators and students. College Student Affairs Journal, 26(2), 136.

Crenshaw, K. (1991). Mapping the margins: intersectionality, identity politics, and violence against women of color. Stanford Law Review, 43, 1241-1299.

Ellis, E. M. (2001) The impact of race and gender on graduate school socialization, satisfaction with doctoral study, and commitment to degree completion. Western Journal of Black Studies, 25(1), 30-45.

Evans, S. (2007). Women of color in American higher education. Thought and Action, 39, 131-138.

Evans-Winters, V., \& Esposito, J. (2010). Other people's daughters: Critical race feminism and Black girls' education. Educational Foundations, 24(1), 1124.

Felder, P. (2010). On doctoral student development: Exploring faculty mentoring in the shaping of African American doctoral student success. The Qualitative Report, 15(2), 455-474.

Gay, G. (2004). Navigating marginality en route to the professoriate: Graduate students of color learning and living in academia. International Journal of Qualitative Studies in Education, 17(2), 265-288.

Gildersleeve, R. E., Croom, N. N., \& Vasquez, P. L. (2011). "Am I going crazy?!": A Critical Race Analysis of doctoral education. Equity \& Excellence in Education, 44(1), 93-114.

Grant, C. M. (2012). Advancing our legacy: A Black feminist perspective on the significance of mentoring from African-American women in educational leadership. International Journal of Qualitative Studies in Education, 25(1), 101-117.

Grant, C., \& Simmons, J. (2008). Narratives on experiences of African-American women in the academy: Conceptualizing effective mentoring relationships of doctoral student and faculty. International Journal of Qualitative Studies in Education 21(5), 501-517.

Griffin, K. A, Muñiz, M. M., \& Espinosa, L. (2012). The influence of campus racial climate on diversity in graduate education. The Review of Higher Education, 35(4), 535-566.

Harris, F. (1999). Centricity and the mentoring experience in academia: An Africentric mentoring paradigm. The Western Journal of Black Studies 23(4), 229-235. 
Herman, C. (2010). Elusive equity in doctoral education in South Africa. Journal of Education and Work, 24(1-2), 163-184.

Hurtado, S., \& Carter, D. F. (1997). Effects of college transition and perceptions of the campus racial climate on Latino college students' sense of belonging. Sociology of Education, 70, 324-345.

Hurtado, S., Milem, J. F., Clayton-Pederson, A. R., \& Allen, W. R. (1999). Enacting diverse learning environments: Improving the climate for racial/ethnic diversity in higher education. Jossey-Bass ASHE Higher Education Report Series (AEHE).

Johnson-Bailey, J., \& Cervero, R. (2008). Different worlds and divergent paths: Academic careers defined by race and gender. Harvard Educational Review, 78, 311-322.

Johnson, D. R., Wasserman, T. H., Yildirim, N., \& Yonai, B. A. (2013). Examining the effects of stress and campus climate on the persistence of student of color and white students: An application of Ban and Eaton's psychological model of retention. Research in Higher Education, 55(1), 75-100.

Jones, C., \& Shorter-Gooden, K. (2004). Shifting: The double lives of Black women in America. New York, NY: HarperCollins.

Ladson-Billings, G. (1999). Just what is critical race theory and what's it doing in a 'nice' field Like education? In L. Parker, D. Deyhle, and S. Villenas (eds.), Race Is . . Race Isn't: Critical Race Theory and Qualitative Studies in Education (pp. 7-30). Boulder, CO: Westview Press.

Lewis, C. W., Ginsberg, R., Davies, T., \& Smith, K. (2004). The experiences of African American PhD students at a predominately White Carnegie I research institution. College Student Journal, 38(2), 231-245.

Lincoln, Y. S., \& Guba, E. G. (1985). Naturalistic inquiry. Beverly Hills, CA: Sage.

Mabokela R. O. (2004). Walking the tightrope: The intersections of race, gender, and culture in higher education. In R. O. Mabokela \& Z. Magubane, (Eds.), Hear our voices: Race, gender and the status of Black South African women in the academy (pp. 59-79). Pretoria: Unisa Press

Mahtani, M. (2004). Mapping race and gender in the academy: The experiences of women of colour faculty and graduate students in Britain, the US and Canada. Journal of Geography in Higher Education, 28 (1), 91-99.

McCabe, J. (2009). Racial and gender microaggressions on a predominantlyWhite campus: Experiences of Black, Latina/o and White undergraduates Race, Gender \& Class, 16, 133-151.

Milem, J.F., Chang, M.J., \& Antonio, A.L. (2005). Making diversity work on campus: A research-based perspective. Washington, DC: American Association of Colleges and Universities.

Nettles, M. T. (1990). Success in doctoral programs: Experiences of minority and White students. American Journal of Education, 98(4), 494-522. 
Patton, M. Q. (1990). Qualitative evaluation and research methods (2nd ed.). Newbury Park, CA: Sage.

Pierce, C. (1970). Offensive mechanisms. In R. Barbour (Ed.), The Black seventies (pp. 265-283). Boston, MA: Poter Sargent.

Pierce, C. (1974). Psychiatric problems of the Black minority. In S. Arieti (Ed.), American handbook of psychiatry (pp. 512-523). New York: Basic Books.

Portnoi, L. (2009). To be or not to be an academic: South African graduate students' vocational choices. International Journal of Educational Development, 29, 406-14.

Potgieter, C. (2008). The intersection of race and gender in the academic environment. National Higher Education Conference: Cape Town, South Africa.

Potgieter, C. A, \& Moleko, A.S. (2004). Stand out, stand up, move out: Experiences of Black South African women at Historically White Universities. In R. O. Mabokela \& Z. Magubane, (Eds.), Hear our voices: Race, gender and the status of Black South African women in the academy (pp. 80-95). Pretoria: Unisa Press

Pratt-Clarke, M. (2010). Critical race, feminism, and education: A social justice model. New York: Palgrave Macmillan.

Pratt-Clarke, M. (2012). A Black woman's search for the transdisciplinary applied social justice model: Encounters with Critical Race Feminism, Black Feminism, and Africana Studies. The Journal of Pan African Studies, 5(1), 83-102.

Shackleton, L., Riordan, S., \& Simonis, D. (2006). Gender and the transformation agenda in South African education. Women's Studies International Forum, 29, 572-580.

Shavers, M. C., \& Moore, J. L. (2014). Black female voices: Self-presentations strategies in doctoral programs at predominately White institutions. Journal of College Student Development, 55(4), 391-407.

Smith, W. A. (2004). Black faculty coping with racial battle fatigue: The campus racial climate in a post-civil rights era. In D. Cleveland (Ed.), $A$ long way to go: Conversations about race by African American faculty and graduate students at predominantly White institutions (pp. 171-190). New York, NY: Lang.

Solórzano, D. G., \& Villalpando, O. (1998). Critical race theory, marginality, and the experience of students of colour in higher education. In C. A. Torres \& T. R. Mitchell (Eds.), Sociology of education: Emerging perspectives (pp. 211-224). Albany, NY: State University of New York.

Solórzano, D. G., Ceja, M., \& Yosso, T. (2000). Critical Race Theory, racial microaggressions, and campus racial climate: The experiences of African American college students. Journal of Negro Education, 69, 60-73. 
Soudien, C. (2010). Entering the gates of the elect: Obtaining the doctorate in education in South Africa. In P. Thomson and M. Walker, (Eds.), The Routledge doctoral student's companion: Getting to grips with research in education and the social sciences (pp. 116-127). London/New York: Routledge.

Strauss, A., \& Corbin, J. (1990). Basics of qualitative research: Grounded theory procedures and techniques. Newberry Park, CA: Sage.

Sue, D. W., Capodilupo, C. M., Torino, G. C., Bucceri, J. M., Holder, A. M. B., Nadal, K. L., \& Esquilin, M. (2007). Racial microaggressions in everyday life: Implications for clinical practice. American Psychologist. 62(4), 271286.

Taylor, E. \& Antony, J. S. (2000). Stereotype Threat reduction and wise schooling: Towards the successful socialization of African American doctoral students in education. The Journal of Negro Education, 69(3), 184-198.

Turner, C. S. V., \& Thompson, J. R. (1993). Socializing women doctoral students: Minority and majority experiences. The Review of Higher Education, 16(3), 355-370.

Wei, M., Ku, T., \& Liao, K. Y. (2011). Minority status stress and college persistence attributions among African America, Asian American, and Latino students: Perception of university environment as a mediator. Cultural Diversity and Ethnic Minority Psychology. 17, 195-203.

Weiss, R. (1994). Learning from strangers: The art and method of qualitative interview studies. New York: The Free Press.

Willie, C., Grady, M., \& Hope, R. (1991). African-Americans and the doctoral experience: Implications for policy. New York: Teachers College Press.

Wing, K. (2003). Critical race feminism: A reader. New York: New York University Press. 